http://dx.doi.org/10.11646/zootaxa.3613.5.5

http://zoobank.org/urn:lsid:zoobank.org:pub:302795EB-72BE-40D5-AD51-F239DAC09A66

\title{
A new species of Tarphius Erichson, 1845 (Coleoptera: Zopheridae) from North Africa and notes on an Iberian species
}

\author{
ARTUR R.M. SERRANO' ${ }^{1}$ ISABEL R. AMORIM ${ }^{2,3} \&$ PAULO A. V. BORGES ${ }^{2,4}$ \\ ${ }^{1}$ Faculdade de Ciências de Lisboa (DZA), Centro de Biologia Ambiental, and Portuguese Platform for Enhancing Ecological \\ Research \& Sustainability (PEERS), R. Ernesto de Vasconcelos, Ed. C2, $3^{\circ}$ Piso, Campo Grande, P-1749-016 Lisboa. \\ E-mail: aserrano@fc.ul.pt \\ ${ }^{2}$ Azorean Biodiversity Group (GBA, CITA-A) and Portuguese Platform for Enhancing Ecological Research \& Sustainability (PEERS), \\ Universidade dos Açores, Departamento de Ciências Agrárias, Rua Capitão João d'Ávila, São Pedro, 9700-042 Angra do Heroísmo, \\ Terceira, Portugal.E-mail: pborges@uac.pt \\ ${ }^{3}$ Centre for Ecology, Evolution and Conservation, School of Biological Sciences, University of East Anglia, Norwich NR4 7TJ, UK \\ ${ }^{4}$ Corresponding author.E-mail: pborges@uac.pt
}

\begin{abstract}
A new species of Tarphius Erichson, 1845 (Coleoptera: Zopheridae, Solier, 1834) is described from Morocco. Tarphius isabelae n. sp. is the fifth Tarphius species recorded in North Africa. In addition, we present some information on the Iberian species, Tarphius kiesenwetteri Heyden, 1870.
\end{abstract}

Key words: Tarphius, taxonomy, new species, Morocco, additional records, Iberian Peninsula

\section{Introduction}

The genus Tarphius Erichson, 1845 is represented in the Palaearctic region by 69 species (Franz 1967; Dajoz 1977; Borges et al. 2008, 2010; Ślipiński \& Schuh 2008; Arechavaleta et al. 2010; Amorim et al. 2012; Machado 2012). Additionally, four species are known from other regions, including two from South America (Franz 1967) and two from the Himalayas (Ślipiński 1985) (see Appendix 1). The only comprehensive catalogue, identification key and descriptions of Tarphius species for the Palaearctic region was provided by Dajoz (1977), which does not include several ( 20) new species that have since been described (see Appendix 1). The vast majority of the Palaearctic species $(90 \%)$ are confined to the Macaronesian archipelagos of the Azores (8 spp.) (Borges et al. 2010), Madeira (23 spp.) (Borges et al. 2008; Machado 2012) and Canaries (31 species) (Arechavaleta et al. 2010; Machado 2012). The remaining Palaearctic species occur in North Africa (4 spp.), Italy (1 sp.) and the Iberian Peninsula (2 spp.) (Ślipiński \& Schuh 2008). The genus has historically been divided into four subgenera (Franz 1967; Dajoz 1977): Tarphius s.str., Glabrotarphius Franz, 1967, Caudatotarphius Franz, 1967 and Atlantotarphius Franz, 1967. However, this division has not always been followed in subsequent works (e.g. Ślipiński \& Schuh 2008).

In the last twenty years, only seven new species of Tarphius have been described (see Appendix 1), suggesting that few novelties remain to be discovered. In spite of this, two species were recently described from Deserta Grande (Madeira archipelago) and Fuerteventura (Canary Islands) (Machado 2012), and additional cryptic species are currently being described from the Azores (Borges et al. in prep.; see also Amorim et al. 2012). In addition, a large effort to collect Tarphius in several locations throughout mainland Portugal, Morocco, Azores and Madeira archipelagos resulted in the discovery and description of a new species from North Africa (Tarphius isabelae n.sp.) and a new locality in continental Portugal for an Iberian species (Tarphius kiesenwetteri Heyden, 1870).

The purposes of this work are to: i) describe a new species of Tarphius from North Africa; and ii) provide additional distributional and natural history information on the Iberian species, T. kiesenwetteri. 


\section{Material and methods}

Specimens of Tarphius were collected exclusively by manual searching in specific habitats (in decaying wood and under bark of live trees) and Berlese funnel extraction from leaf litter. The morphological studies, including measurements and drawings, were performed under a Wild M5 stereoscopic microscope equipped with an ocular micrometer and a drawing tube. Measurements (recorded in millimeters) were taken as follows: head length, from the anterior margin of the frons to the posterior margin of the head; elytral length, at the elytral suture from the apex of the scutellum to the posterior margin of the elytra. Photographs were taken using a Nikkor lens attached to a Canon EOS 5D Mark II camera. Zerene Stacker v.1.04 software was used to stack the images. Image editing was performed in Photoshop CS6.

To perform this study, we compared all species from the Azores (including types) and Iberia, and many species from Madeira and the Canary Islands available in our private collections. P. Oromí and G. Gillerfors provided specimens of many species from the Canary Islands and the Azores, respectively. Descriptions and drawings of North African species (Franz 1967; Dajoz 1977) were sufficient for identification, thus observation of the holotypes of these species was not necessary.

\section{Taxonomy}

\section{Tarphius isabelae Serrano \& Borges, new species}

(Figs. 1, 2)

Type material: HOLOTYPE, female, deposited at the University of the Azores, Terceira, Portugal ("Dalberto Teixeira Pombo" Collection), labelled: Tahanaoute ? Oukaimedem, High Atlas, Morocco, UTM: 29R 603784E, 3463148N (Altitude: 1248 m), 8.III.2007 (Isabel R. Amorim leg.). PARATYPE, 1 female, deposited at the Faculty of Sciences of the University of Lisbon, Portugal, same locality and date as holotype (Isabel R. Amorim leg.).

Etymology. The species is named after Isabel R. Amorim, collector of this new species and Tarphius kiesenwetteri.

Diagnosis (Fig. 1). Medium-sized species (3.33-3.55 mm), shining brown, median area of head, pronotum, and lateral margins of elytra blackish, antennae and legs of a slightly lighter hue; body granulose, each granule bearing a long, thin, fulvous seta; lateral margins of pronotum and elytra strongly serrulate (more evident at humeral angles); elytra parallel in anterior two thirds and slightly acuminate in posterior third, elytral striae wellmarked by large granules, interstriae impunctate; legs and tarsi simple.

Description. Length: 3.33-3.55 mm. Medium size, body convex and ovate, dark brown, setose; dorsal surface bearing large granules (Fig. 1).

Head: granulose, granules large, about as wide in diameter as granule separation; each granule with a puncture bearing a long, erect, needle-like seta. Head with central area darker, almost black; anterior clypeal margin rounded; eyes small, round, glabrous; antenna a little paler than head, with segment II large, globular, segments III, IV and V longer than wide, segments VI and VII as long as wide, segment VIII and IX wider than longer, segments $\mathrm{X}$ and XI forming a compact club (see Table 1).

Pronotum: transverse, widened a little behind middle, 1.7 times wider than long; pronotal disc with median sulcus and bearing large and obtuse granules, which are a little larger than those granules on the head and lateral margins of the pronotum; each granule bears an erect needle-like seta; anterior margin strongly sinuate laterally, anterior angles prominent, nearly acute; lateral margins arcuate, with only one row of elongate, erect setae; posterior angles right; pronotal disc with depressed area in median area near the posterior margin of the pronotum, depression free of granules; postero-lateral margins of pronotum with a slight semi-circular notch.

Elytra: as wide as pronotum, 1.2 times longer than wide, convex, without gibbosities; surface without transverse ridges, with well-marked striae; elytral striae composed of a series of elongate granules; striae in lateral and apical areas with more rounded granules; each granule bears a long, needle-like setae surrounded by a group of 3-6 small seta, forming a "rosette-like" pattern. Note: sometimes the small setae are missing, leaving only the "rosette" setal pattern. 
TABLE 1. Measurements of the two type specimens of Tarphius isabelae n.sp. (all measurements in millimeters). L-Length; W-Width;

\begin{tabular}{|c|c|c|c|c|c|c|c|c|c|c|c|}
\hline $\begin{array}{l}\text { Specimens } \\
\text { /sex }\end{array}$ & L -Total & L-Head & $\begin{array}{l}\text { W- } \\
\text { Head }\end{array}$ & $\begin{array}{l}\text { Head } \\
\text { W/L }\end{array}$ & L- Pron & W-Pron & $\begin{array}{l}\text { Pron } \\
\text { W/L }\end{array}$ & L-Elytra & $\begin{array}{l}\text { W- } \\
\text { Elytra }\end{array}$ & $\begin{array}{l}\text { Elytra } \\
\text { L/W }\end{array}$ & ----- \\
\hline $\begin{array}{l}\text { Holotype } \\
\text { (female) }\end{array}$ & 3.55 & 0.35 & 0.72 & 2.06 & 1.04 & 1.76 & 1.69 & 2.16 & 1.76 & 1.23 & $\begin{array}{ll}---- \\
\end{array}$ \\
\hline $\begin{array}{l}\text { Paratype } \\
\text { (female) }\end{array}$ & 3.33 & 0.42 & 0.80 & 1.91 & 1.02 & 1.68 & 1.65 & 2.08 & 1.82 & 1.14 & ----- \\
\hline \multicolumn{12}{|c|}{ Antenna - Holotype } \\
\hline -------- & Ant1 & Ant2 & Ant3 & Ant4 & Ant5 & Ant6 & Ant7 & Ant8 & Ant9 & Ant10 & Ant11 \\
\hline Total L & 0.144 & 0.096 & 0.064 & 0.056 & 0.048 & 0.040 & 0.040 & 0.032 & 0.040 & 0.048 & 0.080 \\
\hline Total W & 0.088 & 0.067 & 0.045 & 0.040 & 0.040 & 0.040 & 0.040 & 0.048 & 0.064 & 0.12 & 0.11 \\
\hline $\mathrm{L} / \mathrm{W}$ & 1.64 & 1.43 & 1.42 & 1.40 & 1.20 & 1.00 & 1.00 & 0.67 & 0.63 & 0.40 & 0.73 \\
\hline \multicolumn{12}{|c|}{ Antenna - Paratype } \\
\hline --------- & Ant1 & Ant2 & Ant3 & Ant4 & Ant5 & Ant6 & Ant7 & Ant8 & Ant 9 & Ant10 & Ant11 \\
\hline Total L & 0.112 & 0.112 & 0.064 & 0.056 & 0.048 & 0.048 & 0.048 & 0.040 & 0.048 & 0.064 & 0.080 \\
\hline Total W & 0.088 & 0.064 & 0.040 & 0.043 & 0.045 & 0.045 & 0.048 & 0.048 & 0.072 & 0.128 & 0.112 \\
\hline $\mathrm{L} / \mathrm{W}$ & 1.27 & 1.75 & 1.60 & 1.30 & 1.07 & 1.07 & 1.00 & 0.83 & 0.67 & 0.50 & 0.71 \\
\hline
\end{tabular}

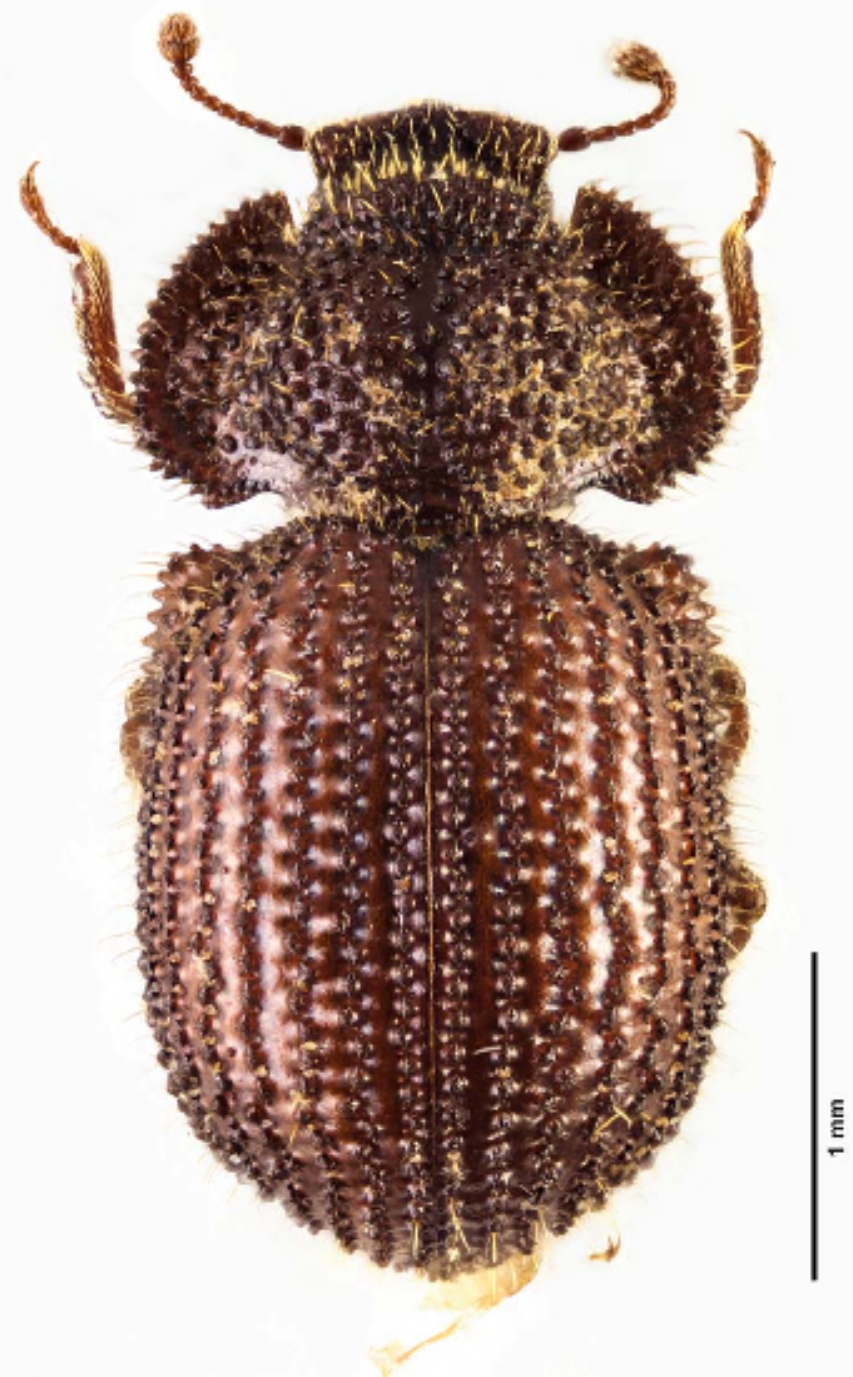

FIGURE 1. Dorsal aspect of Tarphius isabelae Serrano \& Borges n. sp., female holotype (Image credit: E. Mendonça). 


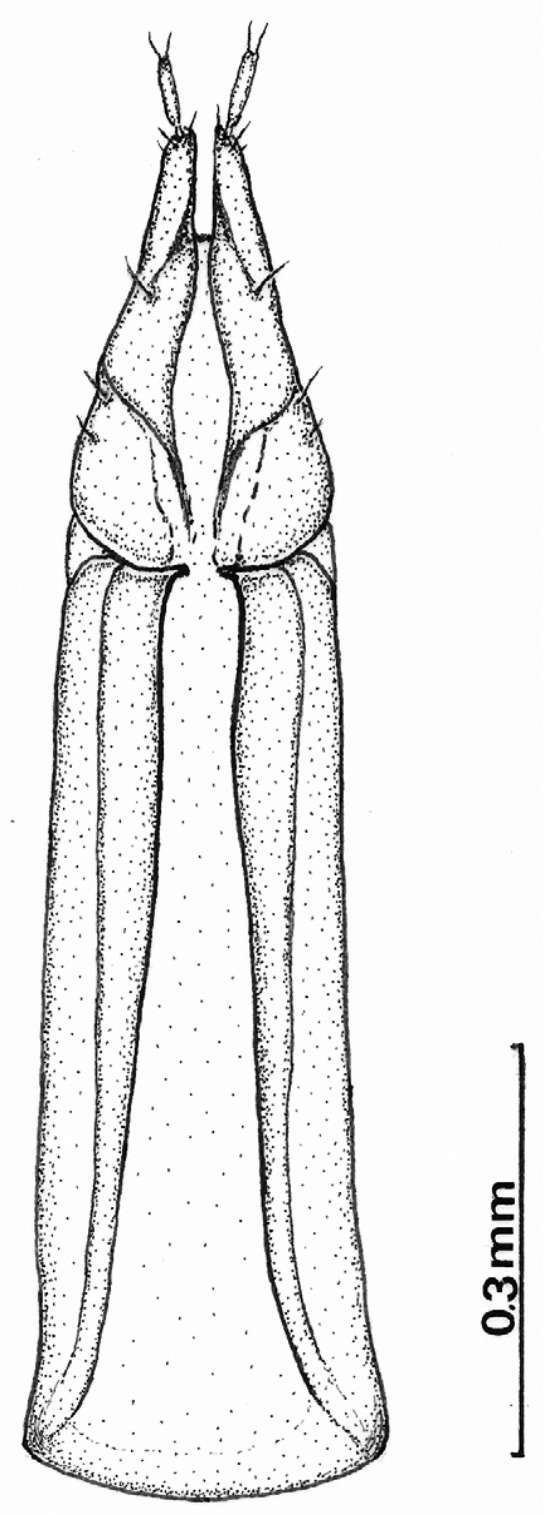

FIGURE 2. Tarphius isabelae Serrano \& Borges n. sp., female genitalia (ventral view).

Ventral surface: prosternum more granulose than meso- and metasternum; hypomeron with a well-marked groove for the reception of the antennae.

Legs: tibiae not expanded apically, tarsi 4-segmented, simple.

Female genitalia (Fig. 2): gonostylus single-segmented, elongate, bearing two long setae at apex; coxites without clear articulations between them. Segment eight glabrous.

Male genitalia: not examined.

Ecological notes. The holotype and paratype were collected in leaf litter of strawberry trees (Arbutus unedo Linnaeus) scattered on a semi-arid mountain slope. Particularly important for the occurrence of Tarphius was the presence of fungal hyphae in the leaf litter where the specimens were found. This is consistent with natural history observations for other members of the genus, suggesting that many Tarphius species could be mycophagus (Wollaston 1854; Dajoz 1977). 


\section{Tarphius kiesenwetteri Heyden, 1870}

(Fig. 3)

Material examined: 16 ex., labelled: Branda do Covelo, Baldosas, Gave, Melgaço, Viana do Castelo, Portugal, UTM: 29R 559685E 4652968N (Altitude: 814 m), 6.XI.2008 (Isabel R. Amorim and Aurora Amorim leg.). Ten specimens are deposited at the University of the Azores, Terceira ("Dalberto Teixeira Pombo" Collection), and 6 specimens are deposited at the Faculty of Sciences of the University of Lisbon, Portugal.

Ecological notes. The specimens were collected in leaf litter in a patch of native forest dominated by sweet chestnut (Castanea sativa Miller) and Pyrenean oak (Quercus pyrenaica Willdenow) trees. The soil was covered by a dense layer of leaf litter with a high density of fungal hyphae.

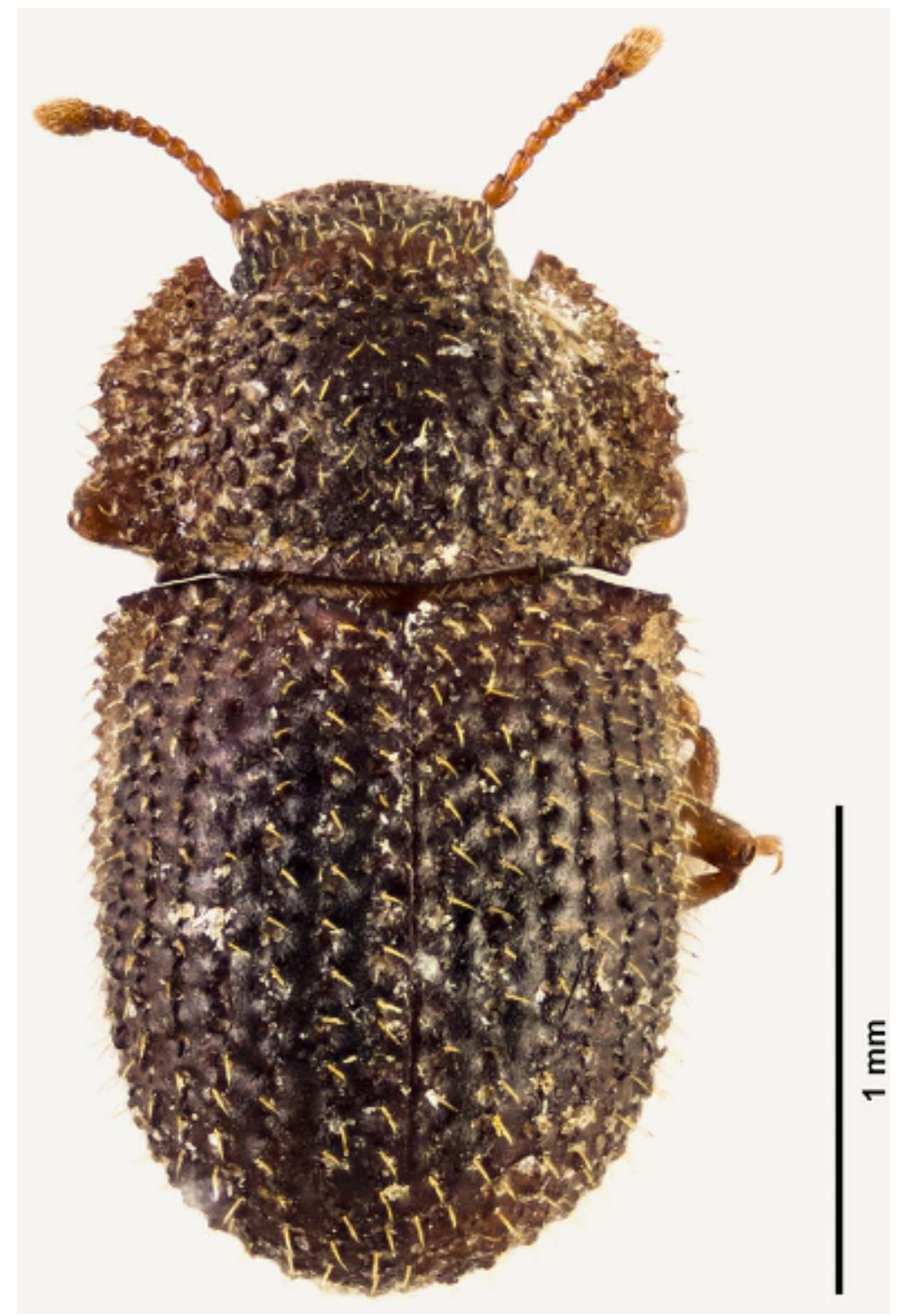

FIGURE 3. Dorsal aspect of Tarphius kiesenwetteri, male (Image credit: E. Mendonça).

\section{Discussion}

Tarphius isabelae n. sp., adds new diversity to the North African assemblage of Zopheridae. The relationships among African Tarphius are unknown due to the absence of phylogenetic analyses; however, it is possible to hypothesize potential relationships based only on morphological similarity. Based on the descriptions in Dajoz (1977), there is clear morphological similarity in the African species, most of them small in size $(\leq 2.7 \mathrm{~mm})$ and having arcuate lateral margins of the pronotum. The unique described African species with medium size $(2.6-3.5$ 
$\mathrm{mm})$, a character shared with the new species $(3.33-3.55 \mathrm{~mm})$, is T. maroccanus Franz, 1967. In both species, some similarity exists in the number of teeth in the lateral pronotal margins (20 vs. 18-20). In the other African species, there are fewer teeth on the pronotal margin (10-14). However, while the two species of Tarphius recorded in Algeria and Tunisia (T. fairmairei Marseul, 1873 and T. liliputanus Lucas, 1847, respectively) exhibit a deep semi-circular notch on each side of the posterior margin of the pronotum, the other two African species known only from Morocco (T. maroccanus and T. oulmesensis Franz, 1967) lack the afore-mentioned notch. In the former species, the sides of the posterior margin are slightly sinuate and are obtuse in the latter (see Figs. 75 and 76 in Dajoz 1977). Interestingly, the notch is present in T. isabelae, but not so strongly developed as in T. fairmairei and T. liliputanus (see Figs. 81 and 82 in Dajoz, 1977). This feature may indicate a closer relationship between $T$. isabelae and the Algerian/Tunisian assemblage or T. gibbulus Germar, 1847 (an Italian species also bearing a semicircular notch on the pronotum) than with the previously described Moroccan species. However, the body size and similar number of teeth on the lateral pronotal margins in $T$. isabelae and T. maroccanus may contradict the previous assumption. Taking into account the vastness of the multiple Moroccan mountain ranges, it is possible that additional new Tarphius species may be discovered.

New distributional information. The Iberian species, T. kiesenwetteri, was originally described from Gerês, Portugal and was later recorded from other localities in the North of continental Portugal and NW Spain (Outerelo \& Gamarra 1995). The new collection locality significantly expands the distribution of $T$. kiesenwetteri, suggesting a wider distribution throughout the native forests of northwest Iberia.

This study, together with the recent findings of Machado (2012) and Amorim et al. (2012), highlights the necessity of additional work to adequately inventory Tarphius species richness in North Africa and Macaronesia.

\section{Acknowledgements}

We are indebted to A. Amorim, D. Amorim, J. Hortal, A. Valverde, and A. Santos for help with specimen collection in Morocco and continental Portugal; to P. Oromí and G. Gillerfors for providing specimens from entomological collections; to Enésima Mendonça for dorsal habitus images; and two anonymous reviewers for their comments and suggestions. This study was supported by grants M2.1.2/I/017/2007 (DRCT, Azores, Portugal), and PTDC/BIA-BEC/104571/2008 (FCT, Portugal). I.R. Amorim was supported by BPD/29578/2006 and PTDC/BIA-BEC/104571/2008 (FCT, Portugal).

\section{Literature cited}

Amorim, I., Emerson, B.C., Borges, P.A.V. \& Wayne, R.K. (2012) Phylogeography and molecular phylogeny of Macaronesian island Tarphius (Coleoptera: Zopheridae): why so few species in the Azores? Journal of Biogeography, 39, 1583-1595. http://dx.doi.org/10.1111/j.1365-2699.2012.02721.x

Arechavaleta, M., Rodríguez, S., Zurita, N. \& Garcia, A. (eds.) (2010) Lista de especies silvestres de Canarias. Hongos, plantas y animales terrestres. 2009. Gobierno de Canarias, $577 \mathrm{pp}$.

Borges, P.A.V., Aguiar, A.M.F., Boieiro, M., Carles-Tolrá, M. \& Serrano, A.R.M. (2008) List of Arthropods (Arthropoda). In: Borges, P.A.V., Abreu, C., Aguiar, A.M.F., Carvalho, P., Jardim, R., Melo, I., Oliveira, P., Sérgio, C., Serrano, A.R.M. \& Vieira, P. (Eds.) A list of the terrestrial fungi, flora and fauna of Madeira and Selvagens archipelagos. Direcção Regional do Ambiente da Madeira and Universidade dos Açores, Funchal and Angra do Heroísmo, pp. 271-356.

Borges, P.A.V., Vieira, V., Amorim, I.R., Bicudo, N., Fritzén, N., Gaspar, C., Heleno, R., Hortal, J., Lissner, J., Logunov, D., Machado, A., Marcelino, J., Meijer, S.S., Melo, C., Mendonça, E.P., Moniz, J., Pereira, F., Santos, A.S., Simões, A.M., Torrão, E. (2010) List of arthropods (Arthropoda). In: Borges, P.A.V., Costa, A., Cunha, R., Gabriel, R., Gonçalves, V., Martins, A.F., Melo, I., Parente, M., Raposeiro, P., Rodrigues, P., Santos, R.S., Silva, L., Vieira, P. \& Vieira, V. (Eds.) A list of the terrestrial and marine biota from the Azores. Princípia, Cascais, pp. 179-246.

Dajoz, R. (1977) Coléoptères: Colydiidae et Anommatidae paléarctiques. Masson, Paris, 260 pp.

Franz, H. (1967) Revision der Tarphius: Arten Europas, Nordwestafrikas und der Kanarischen Inseln (Coleopt., Colydiidae). Eos, 43, 62-81.

Machado, A. (2012) Two new Tarphius species from Macaronesia (Coleoptera, Zopheridae). Journal of Natural History, 46, 637-643. http://dx.doi.org/10.1080/00222933.2012.654477

Outerelo, R. \& Gamarra, P. (1995) Primera cita de Tarphius (Tarphius) kiesenwetteri Heyden, 1870 para España. Descripción de su edeago e nuevos datos sobre su distribución (Coleoptera, Colydiidae). Zapateri, 5, 147-151. 
Ślipiński, S.A. (1985) New and little known species of Colydiidae (Coleoptera) from Asia, Madagascar and Comoro Islands. Annales Zoologici, 39, 181-195.

Ślipiński, S.A. \& Schuh R. (2008) Zopheridae. In: Löbl, I. \& Smetana, A. (Eds.) Catalogue of Palaearctic Coleoptera, Vol. 5. Stenstrup: Apollo Books; pp. 78-87. http://dx.doi.org/10.1603/008.104.0301

Wollaston, T.V. (1854) Insecta Maderensia; being an account of the insects of the islands of the Madeiran group. London: Jan van Voorst, $634 \mathrm{pp}$.

APPENDIX 1. List of Tarphius species of the world.

South America

Tarphius chilensis Franz, 1969

Tarphius peruvianus Franz, 1969

Himalayas

Tarphius bhutanensis Ślipiński, 1981

Tarphius globosus Ślipiński, 1985

Europe

Tarphius besucheti Español, 1961

Tarphius gibbulus (Erichson, 1845)

Tarphius kiesenwetteri Heyden, 1870

North Africa

Tarphius fairmairei (Marseul, 1873)

Tarphius isabelae n.sp.

Tarphius liliputanus (Lucas, 1847)

Tarphius maroccanus Franz, 1967

Tarphius oulmesensis Franz, 1967

Macaronesian Islands

Azores

Tarphius acuminatus Gillerfors, 1986

Tarphius azoricus Gillerfors, 1986

Tarphius depressus Gillerfors, 1985

Tarphius pomboi Borges, 1991

Tarphius rufonodulosus Israelson, 1984

Tarphius serranoi Borges, 1991

Tarphius tornvalli Gillerfors, 1985

Tarphius wollastoni Crotch, 1867

Madeira

Tarphius angusticollis Wollaston, 1860

Tarphius angustulus Wollaston, 1862

Tarphius brevicollis Wollaston, 1854

Tarphius cicatricosus Wollaston, 1854

Tarphius compactus Wollaston, 1854

Tarphius desertaensis Machado, 2012

Tarphius echinatus Wollaston, 1854

Tarphius excisus Wollaston, 1857 
Tarphius explicatus Wollaston, 1857

Tarphius formosus Wollaston, 1857

Tarphius inornatus Wollaston, 1854

Tarphius lauri Wollaston, 1854

Tarphius lowei Wollaston, 1854

Tarphius lutulentus Wollaston, 1871

Tarphius nodosus Wollaston, 1854

Tarphius parallelus Wollaston, 1854

Tarphius rotundatus Wollaston, 1854

Tarphius rugosus Wollaston, 1854

Tarphius sculptipennis Wollaston, 1857

Tarphius sylvicola Wollaston, 1854

Tarphius testudinalis Wollaston, 1854

Tarphius truncatus Wollaston, 1854

Tarphius zerchei Gillerfors, 1997

Canary Islands

Tarphius abbreviatus Wollaston, 1865

Tarphius affinis Wollaston, 1862

Tarphius barbarae Gillerfors, 1991

Tarphius camelus Wollaston, 1862

Tarphius canariensis Wollaston, 1862

Tarphius caudatus Wollaston, 1862

Tarphius congestus Wollaston, 1862

Tarphius deformis Wollaston, 1862

Tarphius elongatus Dajoz, 1971

Tarphius epinae Gillerfors, 1986

Tarphius ericae Gillerfors, 1986

Tarphius erosus Wollaston, 1864

Tarphius fernandez-lopezi Franz, 1967

Tarphius gigas Wollaston, 1862

Tarphius gomerae Franz, 1967

Tarphius huggerti Gillerfors, 1991

Tarphius humerosus Wollaston, 1865

Tarphius jandiensis Machado, 2012

Tarphius monstrosus Wollaston, 1865

Tarphius moyanus Franz, 1967

Tarphius oromii Franz, 1984

Tarphius palmensis Gillerfors, 1990

Tarphius piniphilus Franz, 1967

Tarphius postcostatus Uyttenboogaart, 1937

Tarphius quadratus Wollaston, 1862

Tarphius setosus Wollaston, 1865

Tarphius simplex Wollaston, 1862

Tarphius stagosus Gillerfors \& Oromí, 1991

Tarphius supranubius Franz, 1984

Tarphius tacorontinus Franz, 1967

Tarphius teneriffae Franz, 1967 